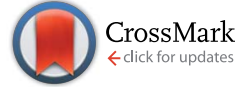

Cite this: RSC Adv., 2017, 7, 8852

Received 14th December 2016 Accepted 22nd January 2017

DOI: 10.1039/c6ra28177j

rsc.li/rsc-advances

\section{Large-scale synthesis of uniformly loaded cobalt nanoparticles on alumina for efficient clean fuel production $\dagger$}

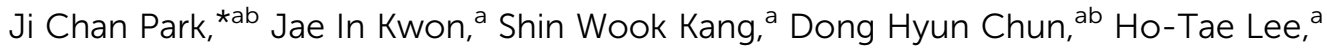 \\ Heon Jung a and Jung-Il Yang*a
}

\begin{abstract}
Large-scale synthesis of cobalt nanoparticles supported on alumina $\left(\mathrm{Co} / \mathrm{Al}_{2} \mathrm{O}_{3}\right)$, which has well dispersed metallic cobalt around $15 \mathrm{~nm}$, was conducted via a simple melt infiltration process of a cobalt hydrate salt and subsequent thermal reduction. The catalytic performance of $\mathrm{Co} / \mathrm{Al}_{2} \mathrm{O}_{3}$ was studied for FischerTropsch synthesis in order to optimize the liquid fuel productivity for target hydrocarbon products controlled by reaction pressures and temperatures. The catalyst showed promising $\mathrm{CO}$ conversions up to $76 \%$ with high hydrocarbon productivity $\left(\sim 1.0 \mathrm{~g}_{\mathrm{HC}} \mathrm{g}_{\mathrm{cat}}{ }^{-1} \mathrm{~h}^{-1}\right)$ and good stability.
\end{abstract}

\section{Introduction}

Fischer-Tropsch synthesis (FTS) is a catalytic polymerization process for converting synthesis gas (a mixture of $\mathrm{CO}$ and $\mathrm{H}_{2}$ ) into long-chain hydrocarbons to produce clean liquid fuels from fossil resources, such as natural gas, biomass or coal..$^{1-3}$ Especially, in the process of synthesis gas derived from natural gas, cobalt supported catalysts have been used because of their high FTS activity and selectivity for linear paraffins. ${ }^{4}$ In recent years, selectivity control for the hydrocarbon products has been a big challenge in FTS., ${ }^{5,6}$ For instance, for the selective production of gasoline-range hydrocarbon products $\left(\mathrm{C}_{5}-\mathrm{C}_{12}\right)$, hybrid cobalt catalysts including zeolite compounds such as ZSM-5 as a cracking catalyst were exploited., ${ }^{7,8}$ Until now, numerous studies on the preparation of cobalt-based FTS catalysts have been reported using various synthetic methods, such as sol-gel, impregnation, co-precipitation, depositionprecipitation, chemical vapour deposition and colloidal methods. ${ }^{9}$ Typically, the preparation variables of metal/ promoter loading, preparation method, pre-treatment, and so on, significantly affect the catalyst performance in FTS. ${ }^{\mathbf{1 0 - 1 4}}$

Study on nano-catalysis has rapidly grown with the addition of new nanomaterials for various catalytic reactions. ${ }^{15-19}$ Along this line, the development of nanostructured catalysts was conducted, not only for fundamental study using computational simulations or theoretical backgrounds, but also for industrial application. ${ }^{20-22}$ Surface science studies, in particular,

${ }^{a}$ Clean Fuel Laboratory, Korea Institute of Energy Research, 152 Gajeong-Ro, Daejeon, 34129, Republic of Korea. E-mail: jcpark@kier.re.kr; Tel: +82-42-860-3605

${ }^{b}$ Advanced Energy and Technology, University of Science and Technology, 217 GajeongRo, Daejeon, 34113, Korea

$\dagger$ Electronic supplementary information (ESI) available. See DOI: 10.1039/c6ra28177j have contributed to fundamental understanding of nanostructured catalyst and catalysis. ${ }^{23}$ However, in many cases, large-scale synthesis of nanocatalysts were still restricted by complex synthetic processes that were expensive and took much time, as well as by environmental problems caused by the use of harmful solvents. In particular, large-scale nanoparticle preparation by solution phase was very difficult. ${ }^{24,25}$ In addition, the nanoparticles prepared using surfactants as stabilizer, have organic layers on their surface, sometimes retarding the activity of the catalyst. ${ }^{26}$

For these reasons, many commercial catalysts, so far, have been produced by a simple process involving mixing, shaking and baking process. It is needed to develop more economical and reproducible mass production methods for nanocatalyst having high activity and promising catalytic performance.

Recently, de Jong et al. reported the melt infiltration process as an emerging technique with no additional solvent use. ${ }^{27}$ It could be utilized as a fast, convenient route to prepare various supported metal catalysts that contain small and well dispersed active nanoparticles inside robust supports. Herein, we demonstrate a simple and eco-friendly preparation method for mass production of $\mathrm{Co} / \mathrm{Al}_{2} \mathrm{O}_{3}$ nanocatalyst, via a melt infiltration process without use of any organic solvent and an optimum thermal reduction condition. A commercially available alumina with high porosity and surface area was exploited as the support for large-scale production of the catalyst. The catalytic performance of the catalyst was optimized by conducting FTS reactions with control of the reaction conditions (10 and 20 bar, $230-260{ }^{\circ} \mathrm{C}$ ). Without additional use of a cracking catalyst, the degree of carbon chain growth was controlled by the $\mathrm{Co} / \mathrm{Al}_{2} \mathrm{O}_{3}$ nanocatalyst under varied reaction conditions. Under the optimum condition, the $\mathrm{Co} / \mathrm{Al}_{2} \mathrm{O}_{3}$ nanocatalyst shows high FTS activity $\left(\sim 1.4 \times 10^{-4} \mathrm{~mol}_{\mathrm{CO}} \mathrm{g}_{\mathrm{Co}}{ }^{-1} \mathrm{~s}^{-1}\right)$, with good stability. 


\section{Experimental}

\subsection{Chemicals}

Cobalt(II) nitrate hexahydrate $\left(\mathrm{Co}\left(\mathrm{NO}_{3}\right)_{2} \cdot 6 \mathrm{H}_{2} \mathrm{O}\right.$, ACS reagent, $\geq 98 \%$ ) was purchased from Sigma-Aldrich. A gamma-alumina powder was obtained from Strem Chemical, Inc. The chemicals were used as received without further purification.

\subsection{Large-scale synthesis of $\mathrm{Co} / \mathrm{Al}_{2} \mathrm{O}_{3}$ nanocatalyst}

For the preparation of the $\mathrm{Co} / \mathrm{Al}_{2} \mathrm{O}_{3}$ nanocatalyst with a theoretical Co load of $15 \mathrm{wt} \%$ in the reduced catalyst, $26.1 \mathrm{~g}$ of $\mathrm{Co}\left(\mathrm{NO}_{3}\right)_{2} \cdot 6 \mathrm{H}_{2} \mathrm{O}$ and $30.0 \mathrm{~g}$ of $\mathrm{Al}_{2} \mathrm{O}_{3}$ was physically mixed in a mortar for several minutes under ambient conditions, until the colour of the powder was homogeneously pink. The mixed powder was then aged in a polypropylene bottle at $60{ }^{\circ} \mathrm{C}$ in a tumbling oven. After aging for $24 \mathrm{~h}$, the sample was cooled under an ambient atmosphere and transferred to an alumina crucible in a furnace. Finally, the cobalt-incorporated alumina powder was slowly heated at a ramping rate of $3.5^{\circ} \mathrm{C} \mathrm{min}^{-1}$ up to $450{ }^{\circ} \mathrm{C}$ under a hydrogen flow of $1.0 \mathrm{~L} \mathrm{~min}^{-1}$. The sample was held at the same temperature for $4 \mathrm{~h}$ under hydrogen gas. After the thermal reduction, the $\mathrm{Co} / \mathrm{Al}_{2} \mathrm{O}_{3}$ nanocatalyst was cooled to room-temperature and immediately submerged in ethanol (0.2 L) under a flow of nitrogen $\left(1.0 \mathrm{~L} \mathrm{~min}^{-1}\right)$ in order to minimize surface oxidation of the cobalt particles. The black powder immersed in ethanol was simply separated by a magnet and dried in a vacuum oven at room temperature. The final $\mathrm{Co} / \mathrm{Al}_{2} \mathrm{O}_{3}$ powder was pressed into pellets; then the resulting catalyst disk was crushed and sieved to yield 300-600 $\mu \mathrm{m}$ particles for a test in a fixed-bed reactor.

\subsection{Fischer-Tropsch synthesis}

Fischer-Tropsch synthesis reactions were performed in a downflow fixed-bed stainless steel reactor tube with an inner diameter of $5 \mathrm{~mm}$. Typically, the catalyst $(0.5 \mathrm{~g})$ was diluted with glass beads (425-600 $\mu \mathrm{m}, 2.5 \mathrm{~g}$ ) to prevent hot-spot generation, and then loaded in the catalyst bed. The reaction was carried out at 230-260 ${ }^{\circ} \mathrm{C}$ under 10 and 20 bar for $48 \mathrm{~h}$ using a reactant gas $\left(\mathrm{H}_{2} / \mathrm{CO}=2.0, \mathrm{GHSV}=6.8 \mathrm{NL} \mathrm{g}_{\text {cat }}{ }^{-1} \mathrm{~h}^{-1}\right)$. The composition of the outlet gases was analysed using a gas chromatograph (DS Science, iGC7200) equipped with a thermal conductivity detector (TCD) and a flame ionization detector (FID). The flow rates of the outlet gases were measured using a wet-gas flow meter (Shinagawa Co.). After FTS reaction for $48 \mathrm{~h}$, the solid hydrocarbon products were collected in a hot trap $\left(240^{\circ} \mathrm{C}\right)$, and the liquid hydrocarbon products and water were collected in a cold trap $\left(0{ }^{\circ} \mathrm{C}\right)$. The isolated wax and liquid products were analysed using an offline gas chromatograph (Agilent, 6890N) and the simulated distillation method (ASTM D2887).

\subsection{Characterization}

The catalysts were characterized using high-resolution transmission electron microscopy (HR-TEM, Tecnai TF30 ST), a titan double Cs corrected TEM (Titan cubed G2 60-300), and high resolution powder-XRD (Rigaku SmartLab). For TEM analysis, samples were prepared by putting a few drops of the corresponding colloidal solutions on lacey carbon-coated copper grids (Ted Pellar, Inc). Hydrogen chemisorption measurement was carried out using a Micromeritics ASAP 2020 C. Before measurement, the sample was heated in flowing hydrogen gas to $400{ }^{\circ} \mathrm{C}$ and was held at the same temperature for $10 \mathrm{~h}$. The $\mathrm{H}_{2}$ adsorption isotherm was measured at $35{ }^{\circ} \mathrm{C}$. Nitrogen sorption isotherms were measured at $-196{ }^{\circ} \mathrm{C}$ with a Tristar II 3020 surface area analyser. Before measurements, the samples were degassed in a vacuum at $300{ }^{\circ} \mathrm{C}$ for $4 \mathrm{~h}$.

\section{Results and discussion}

\subsection{Synthesis of $\mathrm{Co} / \mathrm{Al}_{2} \mathrm{O}_{3}$ nanocatalyst}

Scheme 1 demonstrates the simple procedure for synthesis of $\mathrm{Co} / \mathrm{Al}_{2} \mathrm{O}_{3}$ nanocatalyst with photos of the corresponding materials. A gamma-phase alumina was chosen as support, because it can strongly interact with active nanoparticles, maintaining small cobalt crystallites. ${ }^{28}$ Based on the pore volume of the alumina support used, cobalt nanoparticles were loaded to obtain uniform cobalt dispersion with the optimum Co content. Using a $0.87 \mathrm{~g}_{\text {cobalt salt }} / \mathrm{g}_{\text {alumina }}$ ratio, the active Co nanoparticles were successfully embedded in the porous alumina support. The Co-loading content after the final thermal treatment was calculated to be nominally $15 \mathrm{wt} \%$ on the basis of Co converted from the cobalt nitrate salt. First, the hydrated cobalt salt was melt-infiltrated into the alumina powder by grinding at room temperature with subsequent aging at $60{ }^{\circ} \mathrm{C}$ for $24 \mathrm{~h}$ in a tumbling oven. Next, the infiltrated cobalt salt inside the alumina pore was decomposed into tiny Co nanoparticles by thermal reduction at $450{ }^{\circ} \mathrm{C}$ under a flow of hydrogen. The highangle annular dark-field scanning transmission electron microscopy (HAADF-STEM) image showed bright dots, indicating the Co nanoparticles in the porous alumina support (Fig. 1a). The elemental mapping of cobalt (red) and aluminium (green) demonstrated a uniform particle dispersion without any extremely agglomerated particles (Fig. 1b and e). TEM analysis also revealed the status of Co nanoparticles as black dots (Fig. 1c). The high-resolution TEM (HRTEM) image and corresponding Fourier-transform pattern represented single crystal of metallic cobalt with a distance of $0.205 \mathrm{~nm}$ between neighbouring fringes, which correspond to the (111) planes of facecentered-cubic cobalt (Fig. 1d). The average particle size was measured to be $15.2 \pm 2.7 \mathrm{~nm}$ in the TEM images (Fig. 1c, S1,

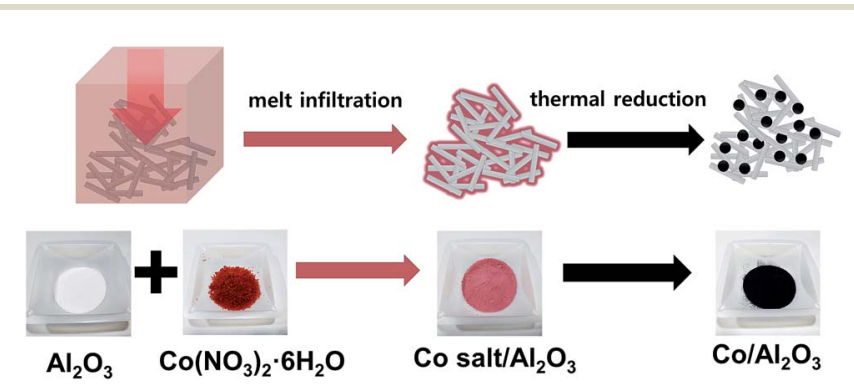

Scheme 1 A facile synthesis of $\mathrm{Co} / \mathrm{Al}_{2} \mathrm{O}_{3}$ nanocatalyst by melt infiltration and thermal treatment. 

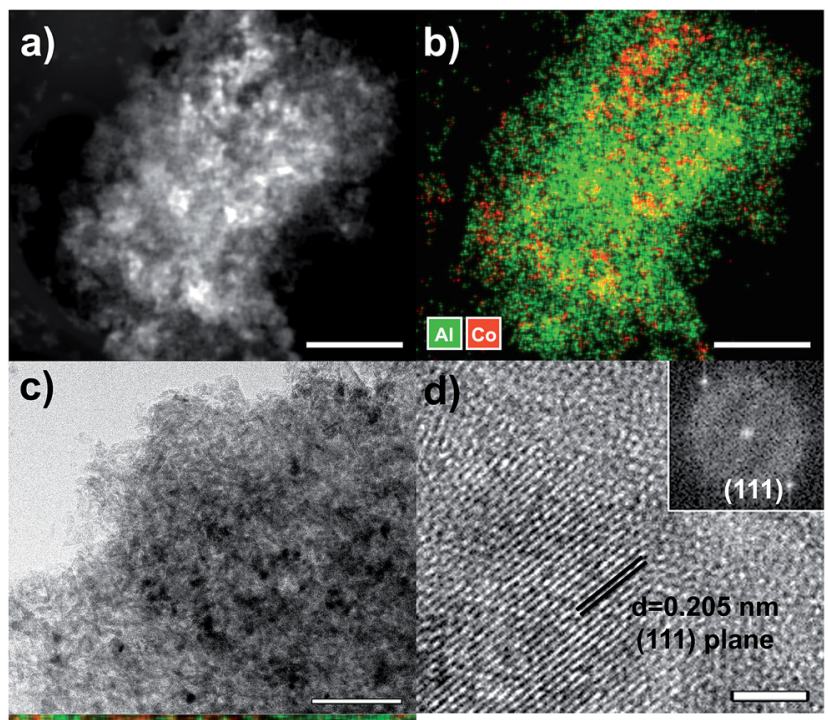

ESI $\dagger$ ). The X-ray diffraction (XRD) spectrum of $\mathrm{Co} / \mathrm{Al}_{2} \mathrm{O}_{3}$ nanocatalyst matched to the metallic Co (JCPDS no. 15-0806; space group, $F m \overline{3} m$ ) and gamma-phase $\mathrm{Al}_{2} \mathrm{O}_{3}$ (JCPDS no. 10-0425; space group, $F d \overline{3} m$ ) (Fig. 1f). Major peaks of alumina were observed at $2 \theta=37.6^{\circ}, 45.9^{\circ}$, and $67.0^{\circ}$. The peak at $2 \theta=44.2^{\circ}$, which was assigned to the reflections of the (111) plane in the fcc-Co, reflects tiny Co single-crystal domain sizes. The average size of the Co crystals was estimated to be $14.2 \mathrm{~nm}$, from the broadness of the (111) peak using the Debye-Scherrer equation, which well-matched that observed in the TEM images. The average cobalt size of $\mathrm{Co} / \mathrm{Al}_{2} \mathrm{O}_{3}$ nanocatalyst was also measured to be $17.1 \mathrm{~nm}$, based on calculation of the Co dispersion (5.62\%) obtained by $\mathrm{H}_{2}$ chemisorption.

$\mathrm{N}_{2}$ sorption experiments for pristine $\mathrm{Al}_{2} \mathrm{O}_{3}$ and the $\mathrm{Co} / \mathrm{Al}_{2} \mathrm{O}_{3}$ nanocatalyst exhibited type IV adsorption-desorption hysteresis. The Brunauer-Emmett-Teller (BET) surface areas of the alumina and the $\mathrm{Co} / \mathrm{Al}_{2} \mathrm{O}_{3}$ nanocatalyst were calculated to be $205 \mathrm{~m}^{2} \mathrm{~g}^{-1}$ and $196 \mathrm{~m}^{2} \mathrm{~g}^{-1}$, respectively (Fig. 2a). The total pore volume of the $\mathrm{Co} / \mathrm{Al}_{2} \mathrm{O}_{3}$ nanocatalyst was found to be $0.31 \mathrm{~cm}^{3}$ $\mathrm{g}^{-1}$, which is about $70 \%$ of the initial alumina $\left(0.44 \mathrm{~cm}^{3} \mathrm{~g}^{-1}\right)$. The significant decrease in the pore volume of the $\mathrm{Co} / \mathrm{Al}_{2} \mathrm{O}_{3}$ nanocatalyst was attributed to the cobalt occupancy. It demonstrates that the cobalt particles are mainly located inside a)

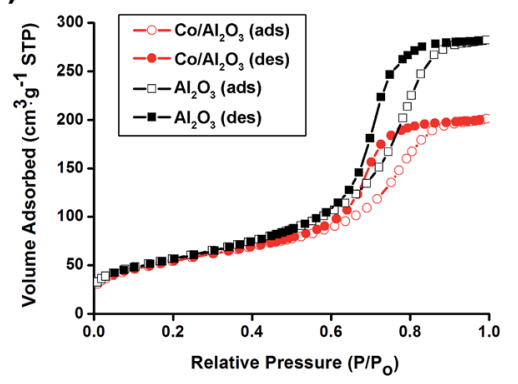

b)

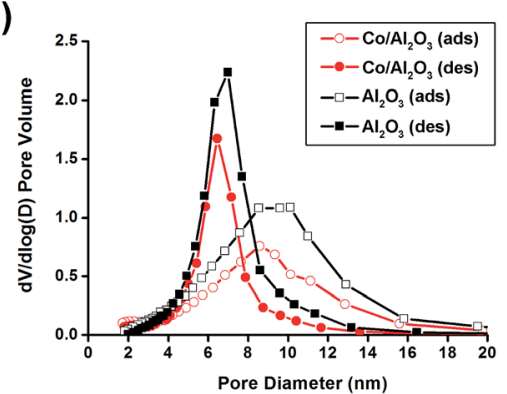

Fig. 2 (a) $\mathrm{N}_{2}$ adsorption/desorption isotherms and (b) pore size distribution diagrams of pristine $\mathrm{Al}_{2} \mathrm{O}_{3}$ and $\mathrm{Co} / \mathrm{Al}_{2} \mathrm{O}_{3}$ nanocatalyst.

the alumina pores, not on the outside. Applying the BarrettJoyner-Halenda $(\mathrm{BJH})$ method, the small pore sizes were obtained by the adsorption/desorption branches (Fig. 2b). Because of the occupancy of the alumina pores by the cobalt particles, the pore size in the $\mathrm{Co} / \mathrm{Al}_{2} \mathrm{O}_{3}$ was also slightly decreased, compared to those of pristine $\mathrm{Al}_{2} \mathrm{O}_{3}(6.5 \mathrm{~nm}$ at the desorption branch and $8.6 \mathrm{~nm}$ at the adsorption branch).

\subsection{Fischer-Tropsch synthesis reaction test}

The catalytic activity of the synthesized $\mathrm{Co} / \mathrm{Al}_{2} \mathrm{O}_{3}$ nanocatalyst was tested for the FTS reaction in a fixed bed reactor (Fig. 3 ). The reactions were carried out at 10 and 20 bar, $230-260{ }^{\circ} \mathrm{C}$, with an $\mathrm{H}_{2} / \mathrm{CO}$ ratio of ' 2 '. In the reactions, CO conversion and hydrocarbon selectivity data were obtained for $48 \mathrm{~h}$ over time-onstream (TOS) by analysing the gas chromatography data of the outlet gasses containing the unreacted $\mathrm{CO}, \mathrm{H}_{2}, \mathrm{CH}_{4}, \mathrm{C}_{2}-\mathrm{C}_{4}$

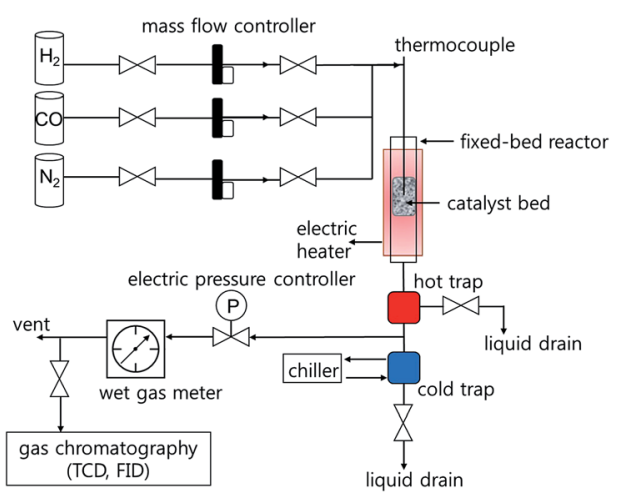

Fig. 3 Schematic diagram of Fischer-Tropsch synthesis reaction instruments. 
hydrocarbons and $\mathrm{CO}_{2}$. Because the active Co phase had been already generated during the catalyst preparation step before the FTS reaction, the $\mathrm{Co} / \mathrm{Al}_{2} \mathrm{O}_{3}$ nanocatalyst could be directly employed in FTS without an additional in situ reduction/ activation process. Under the same temperature conditions, higher CO conversions were measured at 20 bar than 10 bar (Fig. 4). This is, because higher reaction pressure can provide more beneficial conditions in FTS, as follows:

$$
\begin{gathered}
n \mathrm{CO}+(2 n+1) \mathrm{H}_{2} \rightarrow \mathrm{C}_{n} \mathrm{H}_{2 n+2}+n \mathrm{H}_{2} \mathrm{O} \text { (paraffins) } \\
n \mathrm{CO}+2 n \mathrm{H}_{2} \rightarrow \mathrm{C}_{n} \mathrm{H}_{2 n}+n \mathrm{H}_{2} \mathrm{O} \text { (olefins) }
\end{gathered}
$$

Furthermore, the $\mathrm{Co} / \mathrm{Al}_{2} \mathrm{O}_{3}$ nanocatalyst exhibited enhanced $\mathrm{CO}$ conversion with increased reaction temperature (230 to 260 $\left.{ }^{\circ} \mathrm{C}\right)$ under the same reaction pressure condition. At $20 \mathrm{bar}$, the total CO conversion rates were observed to be $36.4 \%$ at $230{ }^{\circ} \mathrm{C}$, $55.8 \%$ at $240{ }^{\circ} \mathrm{C}, 69.2 \%$ at $250^{\circ} \mathrm{C}$, and $76.0 \%$ at $260{ }^{\circ} \mathrm{C}$, at $\mathrm{TOS}=$
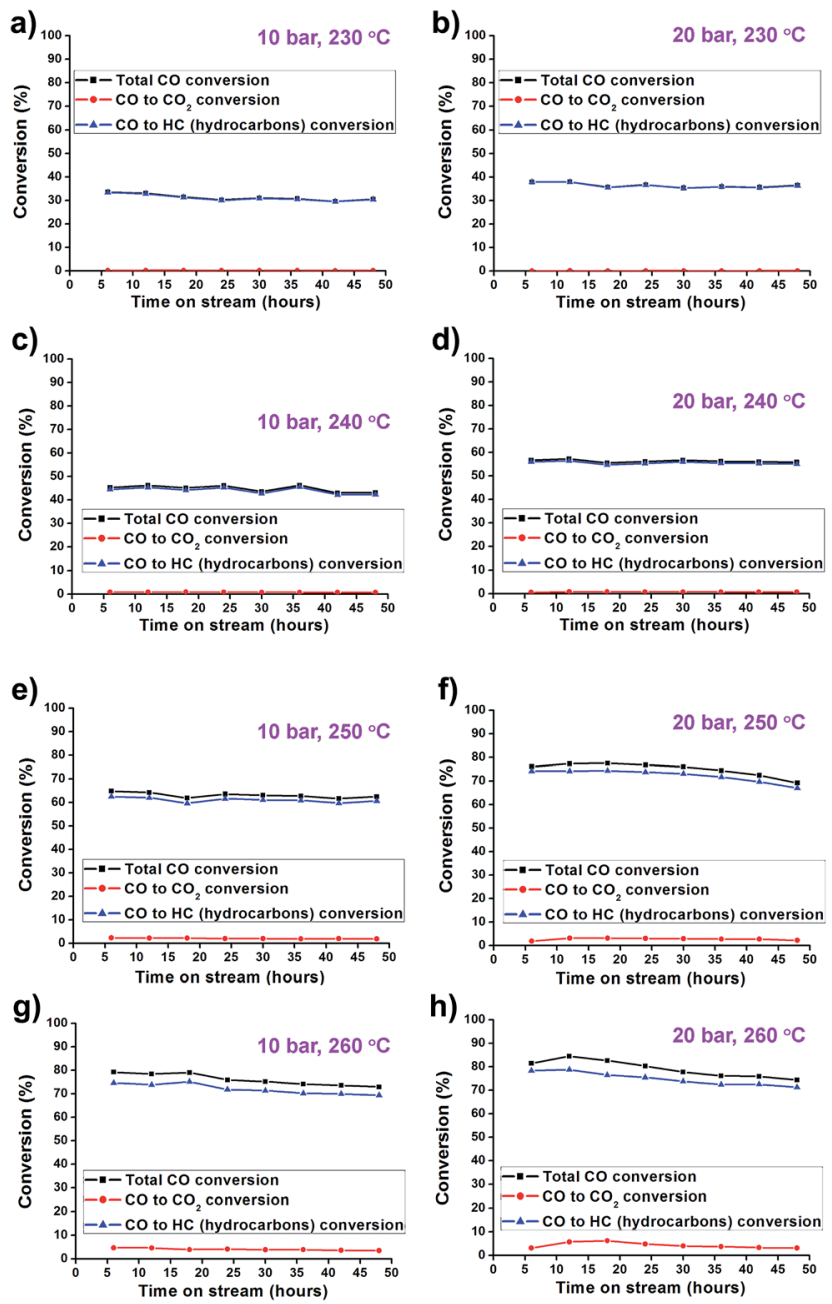

Fig. 4 (a-h) $\mathrm{CO}$ conversion graphs of $\mathrm{Co} / \mathrm{Al}_{2} \mathrm{O}_{3}$ nanocatalyst at $10-$ 20 bar and $230-260^{\circ} \mathrm{C}$. The total CO conversion is the sum of the CO conversion to hydrocarbons $(\mathrm{CO}$ to $\mathrm{HC})$ and the $\mathrm{CO}$ conversion to $\mathrm{CO}_{2}\left(\mathrm{CO}\right.$ to $\left.\mathrm{CO}_{2}\right)$. The reaction tests were conducted at $\mathrm{GHSV}=6.8$ $\mathrm{NL} \mathrm{g} \mathrm{cat}^{-1} \mathrm{~h}^{-1}$ and a $\mathrm{H}_{2}$ : CO ratio of ' 2 '.
$48 \mathrm{~h}$. The highest CO conversion was obtained at 20 bar and $260{ }^{\circ} \mathrm{C}$.

In the selectivity data, increase of the reaction pressure tends to increase $\mathrm{C}_{5+}$ selectivity and decrease $\mathrm{CH}_{4}$ selectivity. This trend leads to the high yield of $\mathrm{C}_{5^{+}}$hydrocarbons (Fig. 5). Under 20 bar, the FTS reaction at $260{ }^{\circ} \mathrm{C}$ showed higher $\mathrm{CO}_{2}(4.3 \%)$, $\mathrm{CH}_{4}(24.0 \%)$, and $\mathrm{C}_{2}-\mathrm{C}_{4}(12.4 \%)$ selectivity and lower $\mathrm{C}_{5+}$ selectivity $(59.3 \%)$ than at lower temperatures. The reaction at $230{ }^{\circ} \mathrm{C}$ showed low $\mathrm{CO}_{2}(0.2 \%), \mathrm{CH}_{4}(13.5 \%)$ and $\mathrm{C}_{2}-\mathrm{C}_{4}(9.2 \%)$ selectivity, and high selectivity for $\mathrm{C}_{5+}(77.1 \%)$. Higher $\mathrm{CO}_{2}$ concentrations in elevated reaction temperatures were mainly attributed to the increased water-gas shift (WGS) reaction as follows:

$$
\mathrm{CO}+\mathrm{H}_{2} \mathrm{O} \leftrightarrow \mathrm{CO}_{2}+\mathrm{H}_{2}
$$

The catalyst activity has been also noted in terms of the Cobalt-Time-Yield (CTY), i.e., the number of CO moles converted to hydrocarbons per gram of cobalt per second over TOS. It can simply reflect the CO conversion and hydrocarbon
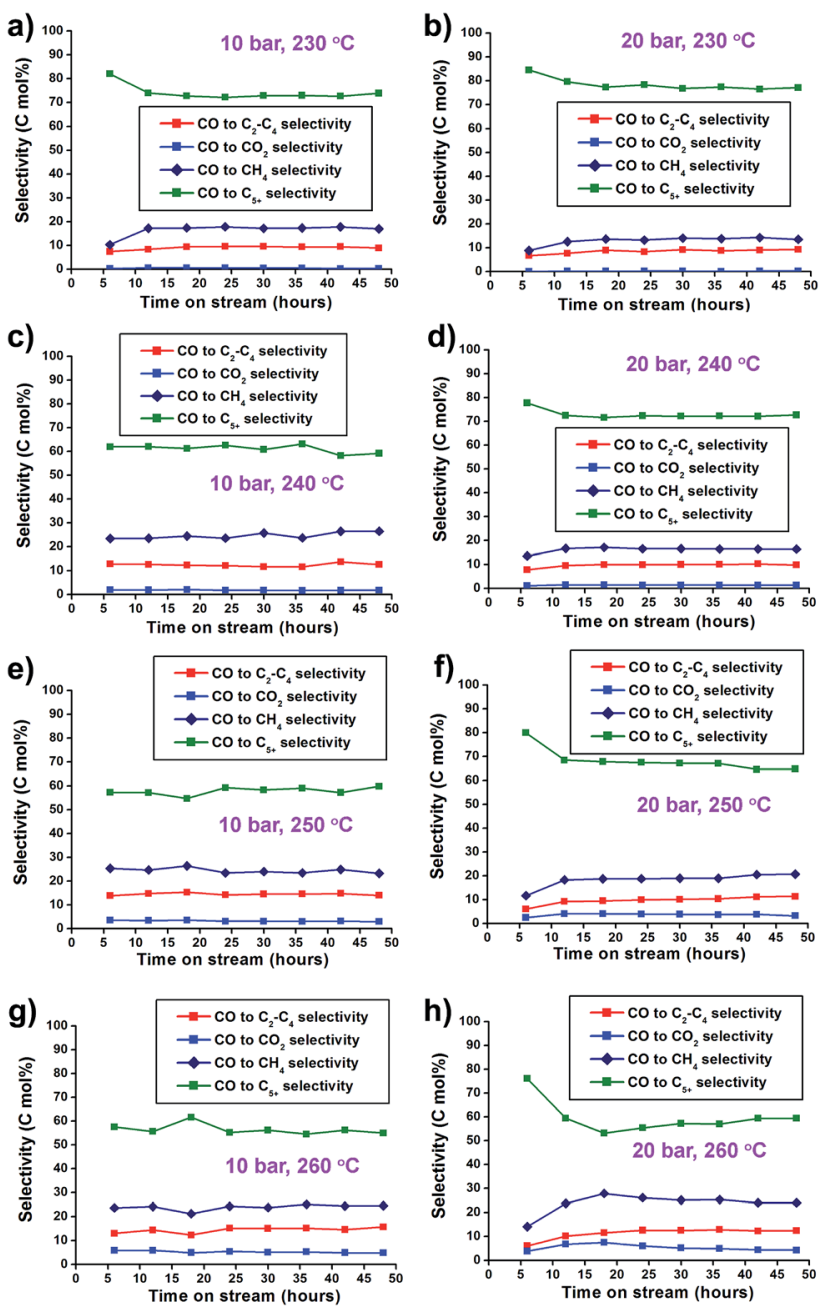

Fig. 5 (a-h) $\mathrm{CO}_{2}$ and hydrocarbon selectivity graphs of $\mathrm{Co} / \mathrm{Al}_{2} \mathrm{O}_{3}$ nanocatalyst at $10-20$ bar and $230-260{ }^{\circ} \mathrm{C}$. The reaction tests were conducted at GHSV $=6.8 \mathrm{NL} \mathrm{g}_{\mathrm{cat}}{ }^{-1} \mathrm{~h}^{-1}$ and a $\mathrm{H}_{2}$ : CO ratio of ' 2 '. 
selectivity of catalysts for each FTS reaction condition. The Co/ $\mathrm{Al}_{2} \mathrm{O}_{3}$ nanocatalyst showed good catalytic performance with high CTY values (Fig. 6). As expected, the catalyst used at the higher reaction temperature of $260{ }^{\circ} \mathrm{C}$ showed much higher CTY values than those of $230-250{ }^{\circ} \mathrm{C}$. In particular, the CTY value at 20 bar and $260{ }^{\circ} \mathrm{C}$ was calculated to be $1.41 \times 10^{-4}$ $\operatorname{mol}_{\mathrm{CO}} \mathrm{g}_{\mathrm{Co}}{ }^{-1} \mathrm{~s}^{-1}$ at TOS $=48 \mathrm{~h}$, comparable with previously reported values of $\mathrm{Co} / \mathrm{Al}_{2} \mathrm{O}_{3}, \mathrm{Co} / \mathrm{C}$, and $\mathrm{Co} / \mathrm{SiO}_{2}$ catalysts (Fig. 6b, Table S1 $\dagger$ ). Increase of the reaction pressure at the same reaction temperatures led to increased CTY values. Controlling temperature was more effective for increasing FTS activity than controlling the reaction pressure, and resulted in high CTY values.

The $\mathrm{Co} / \mathrm{Al}_{2} \mathrm{O}_{3}$ nanocatalyst also showed very high productivity for hydrocarbon products. The specific hydrocarbon productivities were obtained from gas chromatography analysis of gaseous products and simulated distillation analysis of isolated solid and liquid products after FTS reactions (Fig. 7). At 20 bar and $260{ }^{\circ} \mathrm{C}$, the maximum value of the total hydrocarbon (HC) productivity from $\mathrm{C}_{1}$ to $\mathrm{C}_{44}$ was found to be $1.0 \mathrm{~g}_{\mathrm{HC}} \mathrm{g}_{\mathrm{cat}}{ }^{-1}$ $\mathrm{h}^{-1}$. As expected, higher productivity at 20 bar for liquid hydrocarbon $\left(\mathrm{C}_{5^{+}}\right)$was measured than at $10 \mathrm{bar}$. In the case of gasoline-range products $\left(\mathrm{C}_{5}-\mathrm{C}_{12}\right)$, the maximum productivity $\left(0.381 \mathrm{~g}_{\mathrm{HC}} \mathrm{g}_{\text {cat }}{ }^{-1} \mathrm{~h}^{-1}\right)$ was observed under 20 bar at $260{ }^{\circ} \mathrm{C}$ (Fig. 7b). On the other hand, the maximum values for diesel-
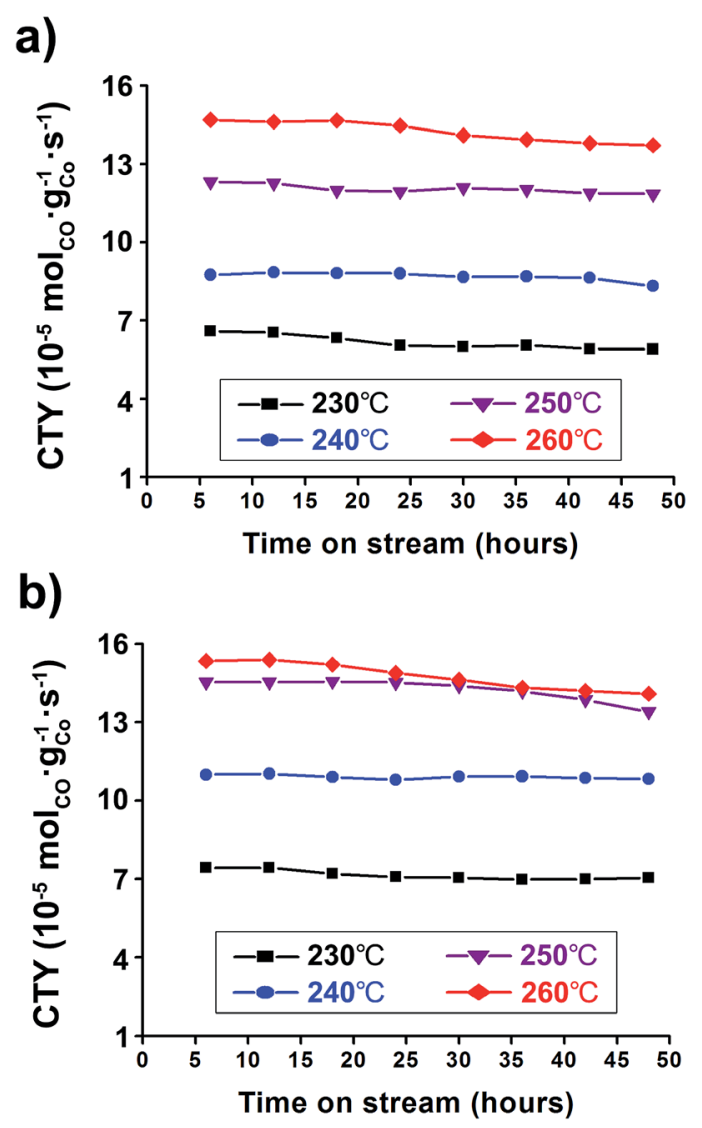

Fig. 6 Cobalt-Time-Yield (CTY) graphs conducted under $230-260^{\circ} \mathrm{C}$ at (a) 10 bar and (b) 20 bar. The reaction tests were conducted at GHSV $=6.8 \mathrm{NL} \mathrm{g}_{\mathrm{cat}}{ }^{-1} \mathrm{~h}^{-1}$ and a $\mathrm{H}_{2}$ : CO ratio of ' 2 '.
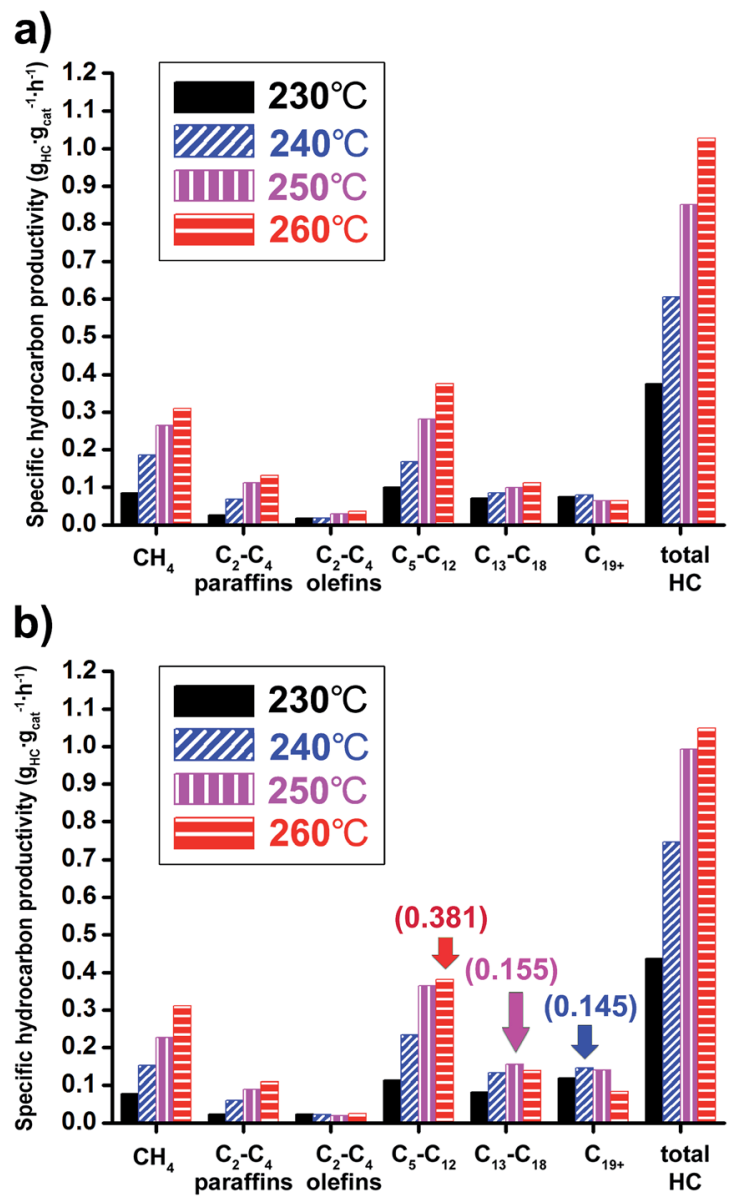

Fig. 7 Hydrocarbon productivity data of $\mathrm{Co} / \mathrm{Al}_{2} \mathrm{O}_{3}$ nanocatalyst conducted under $230-260^{\circ} \mathrm{C}$ at (a) 10 bar and (b) 20 bar. The reaction tests were conducted at GHSV $=6.8 \mathrm{NL} \mathrm{g}_{\mathrm{cat}}{ }^{-1} \mathrm{~h}^{-1}$ and a $\mathrm{H}_{2}: \mathrm{CO}$ ratio of ' 2 '.

range products $\left(\mathrm{C}_{13}-\mathrm{C}_{18}\right)$ and wax-range products $\left(\mathrm{C}_{19+}\right)$ were observed under 20 bar at 250 and $240{ }^{\circ} \mathrm{C}$, respectively.

At 20 bar, the wax-range portion $\left(\mathrm{C}_{19+}\right)$ in total weight portions was significantly decreased with increase of reaction temperatures, indicating $27.1 \%$ at $230{ }^{\circ} \mathrm{C}$ and $8.0 \%$ at $260{ }^{\circ} \mathrm{C}$ (Table S2 $\dagger$ ). On the other hand, the gasoline-range portion $\left(\mathrm{C}_{5^{-}}\right.$ $\left.\mathrm{C}_{12}\right)$ was increased $\left(25.8 \%\right.$ at $230{ }^{\circ} \mathrm{C}$ to $36.3 \%$ at $\left.260{ }^{\circ} \mathrm{C}\right)$.

The chain growth probability $(\alpha)$ of the hydrocarbons can be calculated using the Anderson-Schulz-Flory (ASF) chain growth mechanism in the following equation: ${ }^{29}$

$$
\log \left(W_{n} / n\right)=\log \left(\ln ^{2} \alpha\right)+n \log \alpha
$$

where $W_{n}$ is the weight fraction of hydrocarbons with carbon number $n$. The $\alpha$ values were obtained from the slope of the graph from $\mathrm{C}_{5}$ to $\mathrm{C}_{44}$. The high $\alpha$ value $(0.885)$ at $230{ }^{\circ} \mathrm{C}$ and 20 bar indicate that the high pressure and low reaction temperature can provide more advantageous conditions for carbon chain growth on the catalyst (Table $\mathrm{S} 3 \dagger$ ). This value is apt to produce wax-range hydrocarbons $\left(\mathrm{C}_{19+}\right)$, but for the optimum production of diesel or gasoline range hydrocarbons, the $\alpha$ value should be lower. The obtained values of 0.848 at $250{ }^{\circ} \mathrm{C}$ 
and 0.785 at $260{ }^{\circ} \mathrm{C}$ belong to optimal ranges of diesel $\left(\mathrm{C}_{13}-\mathrm{C}_{18}\right)$ and gasoline $\left(\mathrm{C}_{5}-\mathrm{C}_{12}\right)$ range hydrocarbon products, respectively. ${ }^{30}$

\section{Conclusions}

The Co nanoparticles ( $15 \mathrm{~nm})$ supported on alumina were simply prepared with tens of gram scale in a batch, via melt infiltration and subsequent thermal reduction. This route was reproducible, economically feasible, and eco-friendly. The Co/ $\mathrm{Al}_{2} \mathrm{O}_{3}$ nanocatalyst, with supreme thermal stability and high Co dispersion, showed good CO conversion ( 76\%), very high CTY value $\left(\sim 1.4 \times 10^{-4} \mathrm{~mol}_{\mathrm{CO}} \mathrm{g}_{\mathrm{Co}}{ }^{-1} \mathrm{~s}^{-1}\right)$ and remarkable hydrocarbon productivity $\left(\sim 1.0 \mathrm{~g}_{\mathrm{HC}} \mathrm{g}_{\text {cat }}{ }^{-1} \mathrm{~h}^{-1}\right)$ under controlled FTS conditions. It is anticipated that the optimum reaction conditions for this catalyst could be effectively applied to commercial FTS for producing target liquid fuel products such as gasolineand diesel-range hydrocarbons.

\section{Acknowledgements}

This research was supported by the Research and Development Program of the Korea Institute of Energy Research (KIER) (B62439) and funded by the Ministry of Trade, Industry and Energy (MOTIE) of the Republic of Korea (project no. 10050509).

\section{Notes and references}

1 M. E. Dry, Catal. Today, 2002, 71, 227.

2 E. van Steen and M. Claeys, Chem. Eng. Technol., 2008, 31, 655.

3 A. de Klerk, Green Chem., 2008, 10, 1249.

4 S. K. Beaumont, Phys. Chem. Chem. Phys., 2014, 16, 5034. 5 Q. Zhang, J. Kang and Y. Wang, ChemCatChem, 2010, 2, 1030.

6 Q. Zhang, K. Cheng, J. Kang, W. Deng and Y. Wang, ChemSusChem, 2014, 7, 1251.

7 X. Li, J. He, M. Meng, Y. Yoneyama and N. Tsubaki, J. Catal., 2009, 265, 26-34.

8 J.-C. Kim, S. Lee, K. Cho, K. Na, C. Lee and R. Ryoo, ACS Catal., 2014, 4, 3919.
9 A. Y. Khodakov, W. Chu and P. Fongarland, Chem. Rev., 2007, 107, 1692.

10 K. Shimura, T. Miyazawa, T. Hanaoka and S. Hirata, Appl. Catal., A, 2014, 475, 1.

11 G. Jacobs, T. K. Das, Y. Zhang, J. Li, G. Racoillet and B. H. Davis, Appl. Catal., A, 2002, 233, 263.

12 Y. Ohtsuka, T. Arai, S. Takasaki and N. Tsubouchi, Energy Fuels, 2003, 17, 804.

13 G.-Z. Bian, N. Fujishita, T. Mochizuki, W.-S. Ning and M. Yamada, Appl. Catal., A, 2003, 252, 251.

14 A. Y. Khodakov, Catal. Today, 2009, 144, 251.

15 R. Schlögl and S. B. A. Hamid, Angew. Chem., Int. Ed., 2004, 43, 1628.

16 C. Descorme, P. Gallezot, C. Geantet and C. George, ChemCatChem, 2012, 4, 1897.

17 V. Polshettiwar and R. S. Varma, Green Chem., 2010, 12, 743. 18 Y. Li, Q. Liu and W. Shen, Dalton Trans., 2011, 40, 5811.

19 J. Sun and X. Bao, Chem.-Eur. J., 2008, 14, 7478.

20 J. K. Nørskov, T. Bligaard, J. Rossmeisl and C. H. Christensen, Nat. Chem., 2009, 1, 37.

21 S. Shylesh, V. Schiinemann and W. R. Thiel, Angew. Chem., Int. Ed., 2010, 49, 3428.

22 S. Chaturvedi, P. N. Dave and N. L. Shah, J. Saudi Chem. Soc., 2012, 16, 307.

23 G. A. Somorjai, H. Frei and J. Y. Park, J. Am. Chem. Soc., 2009, 131, 16589.

24 J. Schällibaum, F. H. D. Torre, W. R. Caseri and J. F. Löffler, Nanoscale, 2009, 1, 374.

25 C. Yang, H. Zhao, Y. Hou and D. Ma, J. Am. Chem. Soc., 2012, 134, 15814.

26 H. R. Choi, H. Woo, S. Jang, J. Y. Cheon, C. Kim, J. Park, K. H. Park and S. H. Joo, ChemCatChem, 2012, 4, 1587.

27 T. M. Eggenhuisen, J. P. den Breejen, D. Verdoes, P. E. de Jongh and K. P. de Jong, J. Am. Chem. Soc., 2010, 132, 18318. 28 M. Trueba and S. P. Trasatti, Eur. J. Inorg. Chem., 2005, 3393. 29 I. Puskas and R. S. Hurlbut, Catal. Today, 2003, 84, 99.

30 O. O. James, B. Chowdhury, M. A. Mesubi and S. Maity, RSC Adv., 2012, 2, 7347. 